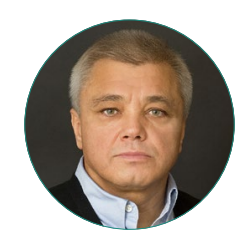

A. V. Rezaev

\title{
TWELVE THESES ON ARTIFICIAL INTELLIGENCE AND ARTIFICIAL SOCIALITY
}

\section{For citation:}

Rezaev A. V. (2021) Twelve Theses on Artificial Intelligence and Artificial Sociality. Monitoring of Public Opinion: Economic and Social Changes. No. 1. P. 20-30. https://doi.org/10.14515/ monitoring.2021.1.1894.

Правильная ссылка на статью:

Резаев А. В. Двенадцать тезисов об искусственном интеллекте и искусственной социальности // Мониторинг общественного мнения: экономические и социальные перемены. 2021. № 1. C. 20-30. https://doi.org/10.14515/monitoring.2021.1.1894. (In Eng.) 
TWELVE THESES ON ARTIFICIAL INTELLIGENCE AND ARTIFICIAL SOCIALITY

Andrey V. REZAEV ${ }^{1}$ - Prof. Dr. habil., Director of International Research Laboratory TANDEM

E-MAIL: rezaev@hotmail.com

https://orcid.org/0000-0002-4245-0769

\section{${ }^{1}$ Saint Petersburg State University, Saint Petersburg, Russia}

Abstract. The Theses deal with the theoretical foundations and methodological implications for scholarly research that arise from the development and implementation of artificial intelligence (Al) technologies into society's daily life. The reader is introduced to age-old intellectual debates about $\mathrm{Al}$ and recent research concerning human-centered $\mathrm{Al}$, artificial sociality (AS), and online culture. The paper presents the working definition of Al. It claims that Al has to be examined in relation to AS. The paper argues that the human-machine-interdependence is a new reality of artificial sociality. It envisages Al research as multidisciplinary and potentially a-disciplinary scientific activity. The questions the Theses raise: What should we be concerned about as artificial intelligence advances? Can Al technologies solve modern society's problems and bring human beings to a new level of community and well-being? Are there 'no-Al areas' in society? Do human biases and prejudices influence Al technologies? The paper's essential assertion is that the challenges posed by Al technologies and AS should be addressed apropos three P's of the capitalist society: private property, profit, price.
ДВЕНАДЦАТЬ ТЕЗИСОВ ОБ ИСКУССТВЕННОМ ИНТЕЛЛЕКТЕ И ИСКУССТВЕННОЙ СОЦИАЛЬНОСТИ

РЕЗАЕВ Андрей Владимирович - доктор философских наук, профессор, руководитель Международной исследовательской лаборатории ТАНДЕМ, Санкт-Петербургский государственный университет, Санкт-Петербург, Россия E-MAIL: rezaev@hotmail.com https://orcid.org/0000-0002-4245-0769

Аннотация. Тезисы формулируют фундаментальные теоретические и методологические проблемы, стоящие перед социальными науками в связи с вхождением технологий искусственного интеллекта (ИИ) в повседневную жизнь общества. Аргументы, развиваемые в тезисах, основаны на классических научных дискуссиях об ии и на современных исследованиях, касающихся человеко-ориентированного ИИ, искусственной социальности и онлайн-культуры. В статье предлагается рабочее определение искусственного интеллекта и обосновывается, что ИИ должен изучаться в связи с искусственной социальностью. Автор утверждает, что взаимозависимость "человек - машина" является новой реальностью искусственной социальности, и рассматривает исследования ИИ как междисциплинарную и потенциально антидисциплинарную научную область. В тезисах рассматриваются следующие вопросы: какие проблемы должны стать предметом внимания социальных ученых по мере развития искусственного интеллекта? Можно ли с помощью технологий ИИ решить проблемы современного общества и вывести его на новый уровень солидарности и материального благополу- 
Keywords: artificial intelligence, artificial sociality, human-machine interdependence, online culture, new social analytics, antidisiciplinarity, human biases, capitalist society чия? Могут ли в современном обществе существовать сферы, свободные от ИИ? Подвержены ли технологии искусственного интеллекта влиянию человеческих предубеждений и предрассудков? В заключение автор формулирует положение о том, что вызовы, обусловленные развитием искусственного интеллекта и искусственной соци альности, необходимо рассматривать в контексте трех основных слагаемых капиталистического общества: частной собственности, прибыли и рыночных отношений.

Ключевые слова: искусственный интеллект, искусственная социальность, взаимозависимость "человек - машина", онлайн-культура, новая социальная аналитика, антидисциплинарность, человеческие предубеждения, капиталистическое общество

Widespread penetration of Artificial Intelligence (Al) in the everyday life of society, the exponential growth of research and publications about Al in computer sciences, natural sciences, and engineering contrasted with the sluggish and precautious efforts to examine $\mathrm{Al}$ in the social sciences and humanities is not a problem, today. It is a fact. What to do about it is a problem.

We proceed from an obvious premise - it is reasonable to think that Al will be part of the real world for human beings in the foreseeable future. It is also reasonable to postulate basic principles for reasoning on $\mathrm{Al}$ and formulate a rationale for scholarly examinations of the Al phenomena. To fulfill this objective, we develop our 12 theses on Al and Artificial Sociality (AS) ${ }^{1}$.

\section{Thesis One: Al appears in the mind of human beings as a combination of the three Ps - Phenomenon, Problem, and Phrase (or a concept) ${ }^{2}$}

As a phenomenon of everyday life, Al cannot be revealed in any other way but in the form of materialized (tangible) products/devices. As such, these devices have a double determination - technical and social. On the one hand, Al appears as a technological device designed to solve a task that is impossible for a human. On the other hand, Al does not exist only in a technical environment. Technologies initially focused on

\footnotetext{
1 [Malsch, 2005] validated AS as a notion for sociological studies.

2 In more detail, we developed our position in [Rezaev, 2020].
} 
instrumental tasks become the environment and participant in human interactions. We call this tendency 'artificial sociality'.

As a research problem, artificial intelligence: (1) raises philosophical (worldview) questions; (2) in a new way characterizes social reality; sheds new light on the specifics and potentials of social reality; calls to reconsider the mainstream visions of social reality; (3) appears differently in different sciences. For natural and engineering sciences, problems of artificial intelligence are related to solving technical and instrumental problems. For sociology and other social sciences, the question of $\mathrm{Al}$ is essentially marginal, a side issue. In philosophy, as in humanities in general, Al is discussed in relation to worldview problems resolved differently in different historical epochs and different intellectual traditions.

As a phrase (concept) in scholarly literature, $\mathrm{Al}$ is not yet defined to have a generally accepted meaning ${ }^{3}$.

However, scholars must agree on defining $A$ l to proceed in rational thinking about Al implementation into the reality of human lives and societal development.

\section{Thesis Two: $\mathrm{Al}$ is not an objectivated thing but an ensemble of formalized rules}

Al's appearance in daily activities as a tangible product should not mislead scholars in determining its substantial nature.

At this juncture of scientific discussions, we have all the foundations to define Al as follows ${ }^{4}$ :

Artificial Intelligence is an ensemble of rational, logical, and formalized instrumental rules developed and coded by human beings that organize the processes and activities to emulate rational/intellectual structures and fabricate and reproduce goal-oriented practices as well as the mechanisms for constructing further coding and decision making.

Five fundamental characteristics underline our definition:

- First, Al is an artifice, a product of human beings, it is not something transcendental or inherently a-social.

- Second, the substantial nature of Al is not something objectifiable as a material gimmick; Al's essence manifests itself as a set of rational and logically formalized rules but not as an attained appliance per se.

- Third, Al is a set of instrumentally coded rules.

- Fourth, an instrumentally coded set of rules is oriented to generate/yield an appliance/product that imitates human beings' intellectual activities.

- Fifth, emulated intellectual constructions make it possible for Al to further independently code and make intellectual or goal-oriented decisions, not necessarily with assistance or control from human beings.

\footnotetext{
3 For a vivid example of this statement, see the recent article on the definition of Al [Wang, 2019] and the subsequent discussion organized in the Journal of Artificial General Intelligence (2020) Vol. 11. No. 2. URL: https://content.sciendo. com/view/journals/jagi/11/2/jagi.11.issue-2.xml (accessed: 17.02.2021).

4 See also: [Rezaev, 2020]. In the attempt to present our working definition of Al we follow the paths proposed in [Russel, Norvig, 2016].
} 


\section{Thesis Three: Al is an inherently non-disciplinary project that brings anti-disciplinarity to academic research}

In today's scholarly world, every discipline creates its objects for study and terminology to establish the borders. For example, although scholars use the common term "nature' in biology and chemistry, the meaning is quite different. Indeed, 'nature' is a core notion for organizing discussion in science, but each discipline has constructed its view on explaining what nature is and how it functions. What biologists understand by nature does not necessarily fit what chemistry or physics define by nature. Disciplinarity turns out to be a real impediment when scholars from various departments meet to resolve a scientific problem, even if it is in the domain of so-called hard sciences. It also applies to 'cross-talk' in social and behavioral sciences.

Further, the sciences are usually distinguished from what is sometimes called the liberal arts, sometimes humanities. Three misconceptions generally accompany this distinction. One is that such division was always in the history of written culture. The second is that it will exist so far as scientific experiments' reality and the reality of words prevail. The third that it is evident from the methods employed in the two fields. However, historically the humanities signified the secular part of the curriculum taught in the medieval church schools (scholae) founded by Charlemagne in the eighth century.

Moreover, no separation of science was apparent until the Renaissance, when a temporary division was imposed due to somewhat superfluous circumstances.

The idea of $\mathrm{Al}$ as a technological innovation for social well-being was introduced in the mid-50s of the last century by a group of scholars who were not oriented in their vision toward one specific discipline ${ }^{5}$. As an object of scholarly interest Al from the very beginning was and could be considered only as a multidisciplinary and potentially a/ anti-disciplinary object. The history of Al development shows that the more stress on interdisciplinarity in research and design, the better the outcomes.

Al must help scholars and humanists merge into one perspective to find new ways of seeing Al and what it is for human beings. It can be done only and if multi-cross-interdisciplinarity methodology evolves into a non-disciplinary structure. Further progress in Al research and design calls for an a-disciplinary approach.

\section{Thesis Four: Human Centered Al calls for new Social Analytics}

There is a sound and justifiable approach to the study and design of Al developed recently by scientists who are at the forefront of Al research. These are predominantly scholars with backgrounds in computer sciences, hard sciences, and technological engineering. Their vision for Al development in society is based on the understanding that Al's mission is to augment and enhance, but not to replace, human beings. The approach is oriented toward cross-multi-disciplinarity. It invites into conversation and co-work on Al representatives from the humanities and the social sciences. It is the most productive approach today. It is called Human Centered Al or Human Centric $\mathrm{Al}^{6}$.

As opposed to pure technology-driven modernization, the importance of humancentered Al surfaces as a useful tool to question, reflect on, and offer alternatives to nor-

\footnotetext{
5 For more details, see [Winograd, 1991] and [McCorduck, 2004].

6 For examples see URL: https://hai.stanford.edu/ (accessed: 08.02.2021) and URL: https://www.humane-ai.eu/ (accessed: 08.02.2021).
} 
mative technology-based everyday practices. The quickest way to express what is at stake here is to say that the point of $\mathrm{Al}$ in society is not that humans have new tools but that they have new tools from someone, for particular purposes, and in a new set of relationships.

Al designers produce what interests them and makes them happy. In their minds, their highest-value product is a new version of their own values. They cannot but define value by what they value. However, designers' values may have nothing to do with the ideals of manufacturers or consumers [see Ford, 2018].

The social sciences and humanities representatives are not yet continually active in studying Al phenomena [Collins, 1992]. Again, the disciplinarity continues to dominate; and philosophers are not in accordance with anthropologists, cultural sociologists with lawyers or economists.

We believe Social Analytics as a general approach that calls for a diversity of scientific methods and theoretical frameworks will achieve more productive results in studying Al at this juncture of scientific investigation of Al phenomena and problems.

Therefore, Social Analytics refers to a lens through which to examine social, legal, ethical, economic, political, engineering problems, intellectual dislocations, exclusions, and challenges for exploring the development and effects of Al phenomena on society.

\section{Thesis Five: For Social Analytics it does not matter whether or not Al will be invented - the point is how to explore the interaction between humans and existing Als}

It does not matter for Social Analytics whether Al (or a General Artificial Intelligence (AGI), also called strong-Al [Goertzel, 2014]) will be invented or not. At this point, there are so many machines that are better at something than humans. Machines can and already do their jobs better than humans. The challenge for social analytics is how to explore the interaction between humans and machines, between machines when humans are off the interaction line.

The real problem for social analytics will be when Al is incorporated into Al research, into studying Al full scale. Now humans study Al in the framework of humans' cycles (time frame, imagination, emotions, etc.). Al as such will have no limits for studying Al. When Google can replace 50000 engineers with ten Al systems, the time scale in science will be driven by machines but not by humans with their objective/subjective constraints.

Despite arguments that Al cannot be understood, in fact, we know more about what $\mathrm{Al}$ is than we know who humans are. Moreover, at the present stage of scientific knowledge development, we have more opportunities for understanding machines and algorithms than for understanding people. The challenge is to see that the human brain is not analogous to computer hardware, and the mind is not comparable to computer software [Dreyfus, 1992; Wolfe, 1993].

Social Analytics' immediate goal is to develop an outlook that goes beyond an 'old paradigm' of Al. It was presupposed for a long time that Al is and can function as an autonomous system or as a robot. This implied that the goal for Al is to replace human jobs. For example, the idea of artificial general intelligence (AGI) is based on the presupposition that machines will emulate human cognition, and there will come a time when $\mathrm{Al}$ - as a superintelligence — will be smarter than humans and take over the world [see Bostrom, 2012; Chalmers, 2010]. 
Social Analytics and Human-Centered approach to Al must formulate a new paradigm based on the partnership and co-existence of humans and Al. It cannot exist without human consciousness that is a hard riddle to resolve in the near future. It means that human intelligence cannot be replaced soon. Thus, humans and Al need to work together. The overall objective for Al is not to confront but to improve the reality of human life. The tasks for humans are to make Al technologies responsible and accountable. The human-machine interdependence is a new reality of artificial sociality. How to code the wider social context of human-human interaction?

\section{Thesis Six: Human-machine interdependence is also a question of trust; it is not only about math}

As a product of a human being, algorithm and data embed historical practices and social biases. You cannot rely on the machine because it is based on data and algorithms.

Recent research shows that there is an issue of algorithmic bias [O'Neil, 2016]. In the reality of human-machine interdependence, the algorithmic bias imposes systemic threats. It is revealed in problems of how human biases interact with the machines' biases. How do biased humans interact with an algorithmic bias, and will this impose systemic threats for Al technologies' implementation in everyday life? How will daily life be affected?

Thus, human-machine interdependence is contested by the value alignment problem.

There are two sides to the question here ${ }^{7}$ : (1) technical — how to give Al (machines) an understanding of human values and goals; how will Al process what humans want, how they feel about certain things, and what is their worldview, and (2) whose values it should be? Society is divided; bankers and housekeepers have different values. The discriminatory codes and designs of Al technologies have the potential to hide, replace social divisions, and amplify racial hierarchies [Benjamin, 2019].

To be biased means to be human, to be a socially organized human being. Biases are due to social class, education, resources availability, culture, religion, gender, sexuality, age. Biases also have purposes and, in different situations, might be helpful or harmful. The objective is to minimize harmful and unintentional biases in the systems of interaction between humans and Al.

There is also the third side. The famous 'Doctor Evil problem': somebody does not care about humanity but cares only about power in the world. It raises fears $\mathrm{s} / \mathrm{he}$ will control Al - this might be even worse when someone takes control over the nuclear bombs. The point is that 'good guys' might also misuse Al and damage humanity. The further development of Al technologies, the more pressure on ethical problems. There is no other way to develop $\mathrm{Al}$ in a society but to base it on moral norms and values. And specific technological issues like how to code human values are related to the fundamental question: what exactly does it mean to code human values?

\section{Thesis Seven: Artificial sociality is contested by the problems of jobs replacement and leisure}

The problem is not where people will work - the question is what people will do with their free time, how to organize their leisure in the age of $\mathrm{Al}$ and $\mathrm{AS}^{8}$.

\footnotetext{
7 For a detailed discussion, see [Russell, 2019].

8 Al technologies and online culture beget specific problems for the youth [see Twenge, 2017].
} 
One of the main fears associated with the development of Al is the loss of jobs. Aristotle also wrote about machines that could replace human labor (in his time slaves' labor). Why were such prospects not a matter of concern in Antiquity? Is not it because modern life is organized around professional activities that bring (a) an income, (b) self-respect and respect for others, and (c) a particular way of life? The ideal type of modern professional is a virtuoso - a narrow specialist (not a master, sage, or community member). The figure of a specialist is opposed by a social activist (volunteer) model who implements abstract principles of justice. The entry of Al into the labor markets leads to the fact that both the specialist and the activist are no longer needed: Al will be useful in solving narrow tasks and at the same time feed the hungry, protect the humiliated, and enlighten the illiterate. What are the remaining charges for people to go through with then?

\section{Thesis Eight: Human sociality is contested by the lack of solitude in the world of algorithms}

Online culture is both an intensive info-instrumental culture and the culture of existential atomization and loneliness. Human loneliness in online activities is intensified by offering the self as the prime source of enjoyment and the only source of agency worth validating ${ }^{9}$.

With the development of online culture, Al technologies penetrate the daily lives of people of all ages and different social statuses on all continents. Online culture changes reality and monetizes social interactions. It translates existential questions into a discussion of social problems and the release of collective emotions. Can a person be able to remain himself/herself in the situation when the machines regulate and mediate communication? Will human-machine interdependence give humans room for privacy?

The question is not in people's access to algorithms - the problem is whether a person can remain solitary and be herself/himself in privacy when the machines organize social interactions?

\section{Thesis Nine: Are there 'no-Al areas' in society?}

There is no sense in going back to a certain point in the history of science and technology, where society turned 'in the wrong direction' for some reason. We should not look for a 'Golden age' in history, but something that will allow society to move forward in entirely new conditions.

The point is not to replace 'imperfect' human activity with perfect Al. People, their life, health, and development are the meaning and ultimate goals of human coexistence in society. Replacing a person with a system of technological tools makes the existence of society meaningless. Only when a person is at the center of socio-political and cultural processes can the gap between people and technology be bridged in the center of society's attention. It is not that human-made technologies are developed to manipulate people, but people manage technology for society's benefit.

The real problem for Human Centered $\mathrm{Al}$ is how to define the areas, places where humans do not have to touch with artificial intelligence, of course, if there are those.

\footnotetext{
9 Spectacular examples you will find in [Turkle, 2011].
} 
Suppose there are such areas that would coordinate and regulate, search and guide the further development of Al. So, the primary task is to find unquestionable taboo areas and how to enforce the taboos for Al.

\section{Thesis Ten: Al progress will continue to change every aspect of life, and society will need to have 'algorithmic auditing companies'}

Al, AS, and online culture will not change human nature, at least in a historically short period of time. However, it is Al that will change the way people are organized. It is Al that will foster new possibilities for constructing and shaping society, affecting and simulating/mimicking the system of social relations. The forms and methods of organizing social relations will continue to change through information flows and modes and channels of communication. The intensity of human-machine interaction, its content, and, accordingly, the conditions for the formation of the prevailing values and ethical norms in society will change.

Thus, the point for scholars is to learn how to orient Al and AS to augment humans and enhance humane in social structures and institutions, to foresee, socially organize inevitable 'human-machine interdependence' and prevent its transformation into something a-societal, to advance society further based on social relations.

Therefore, such questions as "What will we have to change in the system of "human- algorithm interaction" in the future?', 'How to organize auditing of Al entrance in real life of human beings?', 'Who is the owner of Al technologies?' are more essential than the question 'What rewards Al brings to the society?' [see also Etzioni, Etzioni, 2017].

Al technologies make the ownership of the machine and the ownership of intellectual property crucial. We have machines, algorithms, and an increasing number of patents, so the question of who controls the algorithms and owns the patents and the income flow associated with these properties becomes the first question for technology, economy, and politics. The public regulation of Al ownership becomes the first question for society.

\section{Thesis Eleven: Philosophers and Scientists have tried to find similarities between Human Beings and Al, but the point is to see the differences between them}

Humans are not Machines. Humans are not Computers, and Computers are not Humans. The primary deficiency of hitherto-existing views on Al is that scientists look for similarities between what computers are doing and what humans are doing. However, the real need is the opposite: science has to define what are the differences between humans and machines, what makes them unique, and how to enrich humanity via machines and Al.

\section{Thesis Twelve: Al development is framed by the three Ps of capitalism: Private Property, Price, and Profit}

The capitalism that we have today is the kind of capitalism that is empty of purpose, oriented toward the accumulation of capital in order to accumulate more capital. It does not have any articulated objective for societal well-being; it is still based on 
the other three Ps: Private Property, Profit, Price (market ${ }^{10}$ ). And Artificial Sociality will increase capitalism's 'emptiness', or it might increase its social well-being if it is societal mission-driven capitalism ${ }^{11}$.

Of course, due to current discourses developed in media and public at large, society might expect that capitalism with Al and AS will be oriented toward solving the challenging problems for humanity and eliminating the vices of climate change and preserving nature as well as fighting with possible pandemics. However, there is only one mission that current capitalism might have - it is self-preservation, preservation of its three Ps: Private Property, Price, and Profit. At this historical juncture, Al and AS can do nothing but supplement and enhance this mission ${ }^{12}$. The question of what to do with this is both a question of theory and practice.

\section{References}

Benjamin R. (2019) Race After Technology: Abolitionist Tools for the New Jim Code. Oxford (UK): Polity Press.

Bostrom N. (2012) The Superintelligent Will: Motivation and Instrumental Rationality in Advanced Artificial Agents. Minds \& Machines. Vol. 22. No. 2. P. 71-85. https:// doi.org/10.1007/s11023-012-9281-3.

Chalmers D. J. (2010) The Singularity: A Philosophical Analysis. Journal of Consciousness Studies. Vol. 17. No. 9-10. P. 7-65.

Collins R. (1992) Can Sociology Create an Artificial Intelligence? In: R. Collins (ed.) Sociological Insight: An Introduction to Non-Obvious Sociology (2nd ed.). New York, NY: Oxford University Press. P. 155-184.

Dreyfus H. (1992) What Computers Still Can't Do: A Critique of Artificial Reason. Cambridge, MA: MIT Press.

Etzioni A., Etzioni O. (2017) Should Artificial Intelligence Be Regulated? Issues in Science and Technology. Vol. 33. No. 4. P. 32-36. URL: https://issues.org/ perspective-should-artificial-intelligence-be-regulated/ (accessed: 10.02.2021).

Ford M. (2018) Architects of Intelligence: The Truth about Al from the People Building it. Birmingham (UK): Packt Publishing Ltd.

Goertzel T. (2014) The Path to More General Artificial Intelligence. Journal of Experimental \& Theoretical Artificial Intelligence. Vol. 26. No. 3. P. 343-354. https:// doi.org/10.1080/0952813X.2014.895106.

Malsch T. (2005) Kommunikationsanschlüsse. Zur Soziologischen Differenz von Realer und Künstlicher Sozialität. Wiesbaden: VS Verlag für Sozialwissenschaften.

\footnotetext{
${ }_{10}$ Today, specifically after the pandemic, it is clear that a market cannot exist without a government to organised and enforce it. The critical question is to what purpose or whom the market has been organized to serve.

11 Of course, if Human-Centered Approach to Al will be attained.

${ }^{12}$ For more details, see [Zuboff, 2019].
} 
McCorduck P. (2004) Machines Who Think: A Personal Inquiry into the History and Prospects of Artificial Intelligence ( $2^{\text {nd }}$ ed.). Natick: A K Peters.

O'Neil C. (2016) Weapons of Math Destruction: How Big Data Increases Inequality and Threatens Democracy. New York, NY: Crown Publishing Group.

Rezaev A. V. (ed.) (2020) Artificial Intelligence on the Way to Artificial Sociality: New Research Agenda for Social Analytics. Moscow: WSIOM; CrossRoads.

Russell S., Norvig P. (2016) Artificial Intelligence: A Modern Approach. Harlow: Pearson Education Ltd.

Russell S. (2019) Human Compatible: Al and the Problem of Control. London: Penguin Books Ltd.

Turkle S. (2011) Alone Together: Why We Expect More from Technology and Less from Each Other. New York, NY: Basic Books.

Twenge J. M. (2017) iGen: Why Today's Super-Connected Kids Are Growing Up Less Rebellious, More Tolerant, Less Happy — and Completely Unprepared for Adulthood and What That Means for the Rest of Us. New York, NY: Atria Books.

Wang P. (2019) On Defining Artificial Intelligence. Journal of Artificial General Intelligence. Vol. 10. No. 2. P. 1-37. https://doi.org/10.2478/jagi-2019-0002.

Winograd T. A. (1991) Oral History Interview with Terry Allen Winograd. Stanford, CA: Charles Babbage Institute.

Wolfe A. (1993) The Human Difference: Animals, Computers, and the Necessity of Social Science. Berkley, CA: University of California Press.

Zuboff S. (2019) The Age of Surveillance Capitalism: The Fight for a Human Future at the New Frontier of Power. New York, NY: Public Affairs. 